\title{
Application of deep eutectic solvents in promiscuous lipase- catalysed aldol reactions
}

\author{
Daniel González-Martínez, ${ }^{[a]}$ Vicente Gotor, ${ }^{[a]}$ Vicente Gotor-Fernández ${ }^{[a],}$
}

\begin{abstract}
The applicability of deep eutectic solvents has been demonstrated for the first time in promiscuous lipase-catalysed aldol reactions. The model reaction between 4-nitrobenzaldehyde and acetone was examined in depth, an excellent compatibility being found between porcine pancreas lipase and choline chloride: glycerol mixtures for the formation of the aldol product in high yields. The system was compatible with a series of aromatic aldehydes and ketones including acetone, cyclopentanone and cyclohexanone. In some cases the corresponding $\alpha, \beta$-unsaturated carbonyl compounds were found as minor products. Control experiments demonstrate that the enzymatic preparation was also responsible of the collateral dehydration reaction once the aldol product is formed.
\end{abstract}

\section{Introduction}

Biocatalytic promiscuity is gaining considerable attention as a practical tool for the discovery of new enzyme activities. ${ }^{1}$ From the biocatalyst tool-box, the application of hydrolases has quickly gained attention in the development of promiscuous reactions ${ }^{2}$ because of their easy accessibility, lack of cofactor dependency and tolerance to different reaction media, including water, organic solvents, ionic liquids and supercritical fluids. ${ }^{3}$

Hydrolases, but mainly lipases, have displayed significant levels of activity in a variety of non conventional reactions such as carbon-carbon, carbon-heteroatom bond formation reactions and oxidative processes, among others. ${ }^{2,4}$ However, the development of efficient non conventional reactions is still a challenge, and many research groups are devoted to finding broader scope for hydrolase transformations. In the search of sustainable conditions for the development of chemical reactions, deep eutectic solvents (DES) have appeared in recent years as promising biodegradable and environmentally friendly solvents. ${ }^{5}$ DES are generally obtained as homogenous solutions by simply mixing inexpensive hydrogen bond acceptors and donors, usually under heating. Their high boiling points and polarity allows the complete solubility of many different families of products, making their application as green solvents possible. ${ }^{6}$

\footnotetext{
[a] D. González-Martínez, V. Gotor, V. Gotor-Fernández Departamento de Química Orgánica e Inorgánica Instituto Universitario de Biotecnología de Asturias Universidad de Oviedo, 33006 Oviedo, Spain E-mail: vicgotfer@uniovi.es Website: bioorganica.grupos.uniovi.es
}

Supporting information for this article is given via a link at the end of the document.
Eutectic mixtures have attracted increasing attention in a variety of fields such as lubricants, ${ }^{7}$ nanomaterials, ${ }^{8}$ pharmaceuticals ${ }^{9}$ and separation techniques. ${ }^{10}$ More closely to organic synthetic applications, DES have efficiently catalysed multiple traditional organic ${ }^{11}$ and organometallic reactions, ${ }^{12}$ but the application in biocatalysed transformations is still rare. ${ }^{13}$ Until now, the activities of hydrolases, ${ }^{14}$ oxidoreductases $^{15}$ and lyases $^{16}$ have been already demonstrated in high-yielding transformations using DES as medium. DES have been also able to run tandem enzyme-organocatalyst aldol reactions, ${ }^{17}$ and as far as we know only Shukla and coworkers have reported their use as reaction media in a strictly enzyme promiscuous catalytic process such as the Biginelli reaction for the synthesis of novel dihydropyrimidin-2(1H)-ones derivatives. ${ }^{18}$

Herein, we wish to report the benefits of applying DES as reaction media for non conventional reactions. As a proof of concept, a series of hydrolases will be screened in crossed aldol reactions, searching for adequate and mild reaction conditions in the development of carbon-carbon bond formation reactions. The benefits of an efficient and simple isolation of the resulting aldol products will be explored, attempting also the recycling of the catalytic system.

\section{Results and Discussion}

Hydrolase-catalysed aldol reaction between 4nitrobenzaldehyde and acetone

The reaction between 4-nitrobenzaldehyde (1a) and acetone (2) was tested as the model biotransformation in order to explore the suitability of DES as reaction medium for hydrolase-catalysed promiscuous aldol processes (Scheme 1). The mixture composed by choline chloride and glycerol (ChCl:Gly, $1: 1.5 \mathrm{~mol} / \mathrm{mol}$ ) was selected as initial starting point based on the suitability of this hydrogen bond donor and acceptor in previous studied biotransformations. Three enzymes were initially selected based on their already demonstrated activity as efficient catalyst in the formation of aldol products: Candida antarctica lipase type B (CAL-B), ${ }^{19}$ protease from Bacillus lincheniformis (Alcalase-CLEA $\left.{ }^{\circledR}\right)^{20}$ and porcine pancreas lipase (PPL). ${ }^{21}$

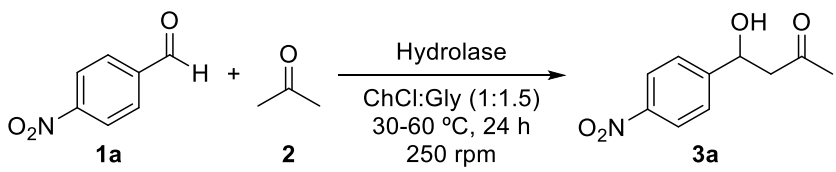

Scheme 1. Hydrolase-catalysed aldol reaction between 4-nitrobenzaldehyde and acetone in ChCl:Gly (1:1.5 mol/mol) after $24 \mathrm{~h}$ at $250 \mathrm{rpm}$. 
Attempts to follow the biotransformations by GC analysis were unsuccessful since the retro-aldol reaction occurred at the high temperatures used in the analysis, so we decided to fix a 1 day reaction time and measure the conversions using ${ }^{1} \mathrm{H}$-NMR analysis. A simple extraction procedure with ethyl acetate was performed to separate the DES and the biocatalyst from the aldol $\mathbf{3 a}$. The results are summarised in Figure 1.

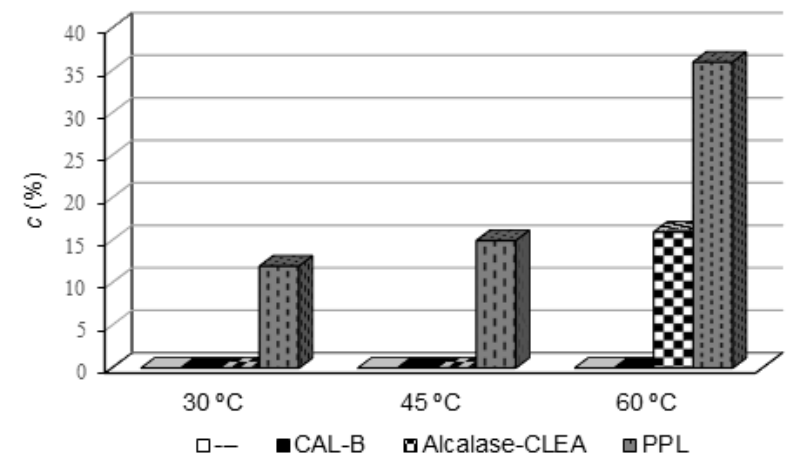

Figure 1. Enzyme-catalysed aldol reaction between 4-nitrobenzaldehyde (1a $0.1 \mathrm{M})$ and five equivalents of acetone (2) in ChCl:Gly $(1: 1.5 \mathrm{~mol} / \mathrm{mol})$ after 24 $\mathrm{h}$ at $250 \mathrm{rpm}$. CAL-B and PPL were used in a 1:1 ratio enzyme:1a $(\mathrm{w} / \mathrm{w})$, while for Alcalase-CLEA the ratio was 2:1.

First of all, it is worth mentioning that no reaction was observed at 30,45 or $60 \stackrel{\circ}{\circ}$ in the absence of enzyme, discarding the possibility of the non enzymatic reaction. No reaction was either observed when using CAL-B as biocatalyst, and just a poor conversion was observed for the Bacillus lincheniformis protease (Alcalase-CLEA)-catalysed reaction at high temperatures. Satisfyingly, PPL was found as an active enzyme in these conditions, observing also the formation of the aldol-dehydration product $\mathbf{4 a}$ as a minor product (ratio $7: 1$ ) but only at $60^{\circ} \mathrm{C}$. These conditions served as a good starting point for optimization.

Optimization of reaction parameters for the biocatalytic
aldol reaction between 4-nitrobenzaldehyde and acetone

In order to achieve higher conversions, biotransformations were attempted at higher substrate concentrations (Table 1). In this case special attention was paid to the distribution of products, as a mixture of the aldol $\mathbf{3 a}$ and the aldoldehydration product $\mathbf{4 a}$ was obtained. The formation of $\mathbf{3 a}$ was favored in all cases (entries 1-3), achieving a noteworthy $90 \%$ conversion in the reaction with 4-nitrobenzaldehyde at 1 $\mathrm{M}$ (entry 3). Interestingly, no reaction was observed in these conditions in the absence of catalyst, so the catalytic potential of PPL was demonstrated for this transformation (entry 4). Reactions at $0.1 \mathrm{M}$ aldehyde concentration were also performed in other choline chloride-based DES. On one hand, the use of $\mathrm{ChCl}$ :urea $(1: 2 \mathrm{~mol} / \mathrm{mol})$ allows a quantitative conversion after $24 \mathrm{~h}$ at $60^{\circ} \mathrm{C}$, but a low product recovery was observed after the extraction purification. On the other hand, the use of $\mathrm{ChCl}$ :ethylene glycol $(1: 2 \mathrm{~mol} / \mathrm{mol})$ provided a mixture of the expected products, but also some ethylene glycol was extracted from the DES, which made us decide to continue with the use of glycerol-based solvents for further optimization.

Table 1. PPL-catalysed aldol reaction between 4-nitrobenzaldehyde and acetone in ChCl:Gly $(1: 1.5 \mathrm{~mol} / \mathrm{mol})$ after $24 \mathrm{~h}$ at $60^{\circ} \mathrm{C}$ and $250 \mathrm{rpm}$.

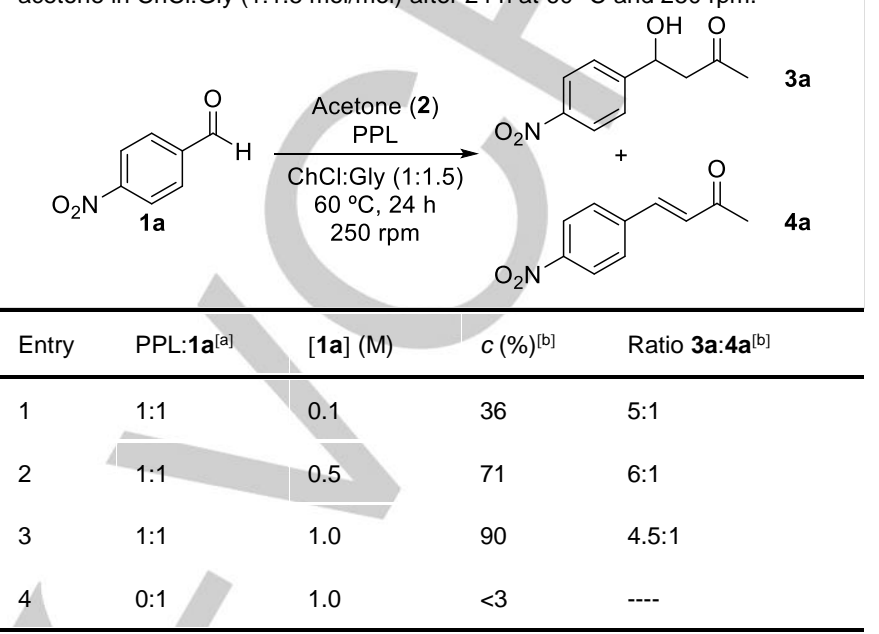

[a] Ratio PPL:1a $(w / w)$. [b] Conversion values and ratio of products 3a:4a were determined by ${ }^{1} \mathrm{H}-\mathrm{NMR}$ of the reaction crudes.

Next, several parameters were analysed in the PPLcatalysed process between 4-nitrobenzaldehyde and acetone trying to identify optimal reaction conditions for quantitative conversions. Thus, we decided to study the influence of the loading of enzyme, the use of other DES mixtures and percentages of water in the solvent system. The reaction time and temperature were fixed at $24 \mathrm{~h}$ and $60{ }^{\circ} \mathrm{C}$, respectively, and the results are summarised in Table 2.

Taking into account the decisive role of water for the development of efficient promiscuous hydrolase-catalysed reactions, ${ }^{22}$ a small percentage of water $(20 \% \mathrm{v} / \mathrm{v})$ was initially added to the DES. A complete conversion and a similar ratio were found in comparison with the process in absence of water (entries 1 and 2). The use of a DES with higher glycerol content was also tested, finding a similar reactivity towards the complete disappearance of the starting 4-nitrobenzaldehyde (entry 3 ), reaction that did not occur in any extension in the absence of biocatalyst (entry 4).

At this point the loading of enzyme was reduced by half but, in these conditions, conversions around $80 \%$ were found with both DES (entries 5 and 6), although a remarkable higher proportion of the aldol was observed at less amount of enzyme. This observation was confirmed by an experiment where the aldol product 3a was incubated in DES at $60^{\circ} \mathrm{C}$ and in the presence of PPL, as the dehydration product was formed in $43 \%$ conversion after 24 hours while the reaction in absence of enzyme just proceeded in a minimum extent (4\% conversion). An additional experiment was made using inhibited PPL, ${ }^{23}$ observing only a $12 \%$ of the dehydration product $\mathbf{4 a}$, fact that suggest that a specific catalysis is occurring for the transformation of $\mathbf{3 a}$ into $\mathbf{4 a}$. These control 
experiments highlight the role of the enzymatic preparation in the concomitant dehydration process.

Table 2. PPL-catalysed aldol reaction between 4-nitrobenzaldehyde $(1 \mathrm{M})$ and acetone in $\mathrm{ChCl}$ :Gly mixtures after $24 \mathrm{~h}$ at $60{ }^{\circ} \mathrm{C}$ and $250 \mathrm{rpm}$.

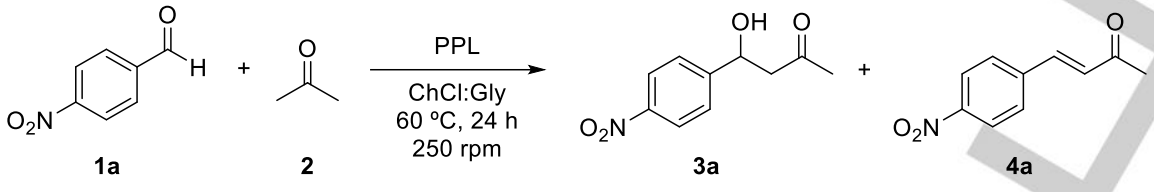

\begin{tabular}{|c|c|c|c|c|c|c|}
\hline Entry & PPL:1a ${ }^{[a]}$ & Solvent $t^{[b]}$ & 2 (equiv.) & $\mathrm{H}_{2} \mathrm{O}(\%)^{[\mathrm{c}]}$ & $c(\%)^{[b]}$ & Ratio $3 \mathbf{a}: 4 \mathbf{a}^{[\mathrm{d}]}$ \\
\hline 1 & $1: 1$ & ChCl:Gly (1:1.5) & 5 & 0 & 90 & $4.5: 1$ \\
\hline 2 & $1: 1$ & ChCl:Gly (1:1.5) & 5 & 20 & $>97$ & $6: 1$ \\
\hline 3 & $1: 1$ & ChCl:Gly (1:2) & 5 & 20 & $>97$ & $6: 1$ \\
\hline 4 & $0: 1$ & ChCl:Gly (1:2) & 5 & 20 & $<3$ & --- \\
\hline 5 & $1: 2$ & ChCl:Gly (1:1.5) & 5 & 20 & 80 & $10: 1$ \\
\hline 6 & $1: 2$ & ChCl:Gly (1:2) & 5 & 20 & 82 & $11: 1$ \\
\hline 7 & $1: 2$ & ChCl:Gly (1:2) & 5 & 5 & 80 & $10: 1$ \\
\hline 8 & $1.5: 2$ & ChCl:Gly (1:2) & 5 & 5 & 89 & $6: 1$ \\
\hline 10 & $1: 2$ & ChCl:Gly (1:2) & 2.5 & 5 & 54 & $6.5: 1$ \\
\hline 11 & $1: 2$ & ChCl:Gly (1:2) & 1 & 5 & 25 & $6: 1$ \\
\hline 12 & $1: 1^{[\mathrm{e}]}$ & ChCl:Gly (1:2) & 5 & 5 & 9 & $3: 1$ \\
\hline 13 & $1: 2$ & Toluene & 5 & 0 & 8 & $5.5: 1$ \\
\hline
\end{tabular}

[a] Ratio enzyme:substrate (w/w). [b] Ratio ChCl:Gly (mol/mol). [c] Percentage in volume of water in the reaction medium. [d] Conversion values and ratio of products 3a:4a determined by ${ }^{1} \mathrm{H}-\mathrm{NMR}$ of the reaction crudes. [e] Enzyme pre-treated with PMSF for $16 \mathrm{~h}$ at $30^{\circ} \mathrm{C}$.

A similar result was also observed when just $5 \%$ of water was used in combination with the ChCl:Gly (1:2) as reaction medium (entries 7 and 8), which means that minimum amounts of water are required to design an efficient protocol towards the formation of the aldol product $3 \mathbf{a}$. The process seems to be more effective at higher enzyme loadings to achieve a complete conversion after $24 \mathrm{~h}$ (entry 9). The use of different equivalents of acetone was also explored, clearly observing the necessity of a considerable excess of the donor ketone to obtain good conversion values (entries 7, 10 and 11).

Remarkably, a control experiment with the inhibited PPL after treatment with phenylmethanesulfonyl fluoride (PMSF), a commonly used serine protease inhibitor, ${ }^{23}$ demonstrating again the catalytic activity of the enzyme (entry 12). Interestingly, when a non polar organic solvent such as toluene, commonly employed in lipase-catalysed reactions, was used in the optimised conditions the conversion just reached a low $8 \%$ conversion, giving extra value to the process developed in DES systems (entry 13).

Next, the use of different substrate concentration in the ChCl:Gly ( $\mathrm{mol} / \mathrm{mol}$ ) was explored (Figure 2), finding the 1 and $2 \mathrm{M}$ concentrations of $\mathbf{1 a}$ as the best conditions for practical applications, while much higher substrate concentrations (3-6 M) led to a slightly decrease in the conversion value. Nonetheless, a conversion range between $75-80 \%$ was still found for these high-substrate concentration reactions without varying significantly the ration of products. Significantly, in the absence of DES just a $54 \%$ conversion was reached, which highlights the use of DES for synthetic purposes.

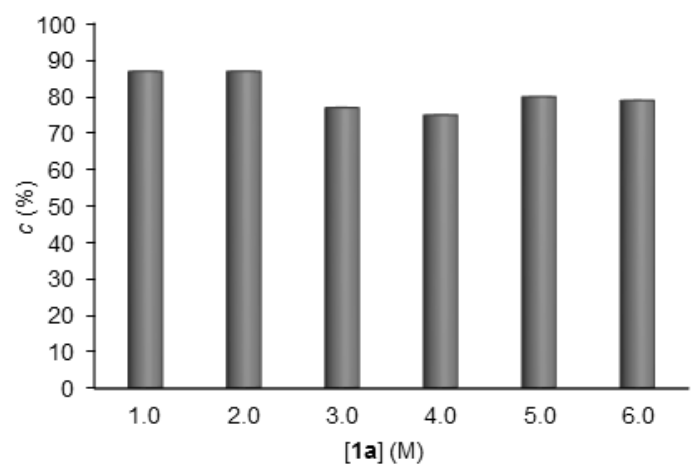

Figure 2. PPL-catalysed aldol reaction between 1a (enzyme:1a ratio $1: 2 \mathrm{w} / \mathrm{w}$ ) and 5 equiv. of acetone in ChCl:Gly $(1: 2, w / w)$ containing a $5 \%$ of water after $24 \mathrm{~h}$ at different aldehyde concentrations. 
Before extending the optimal conditions to a representative number of substrates we focused in the type of agitation, considering different speeds for orbital shaking or alternatively the use of a magnetic stirrer. Overall, no significant differences were observed in the distribution of aldol $\mathbf{3 a}$ and aldol-dehydration $\mathbf{4 a}$ products in different shaking conditions. All the reactions were carried out for $24 \mathrm{~h}$ at $60{ }^{\circ} \mathrm{C}$ using 5 equiv. of acetone and $5 \%$ of water in different DES and the results are summarised in Figure 3. As it can be seen, the use of the orbital shaker at intermediate speeds provides the best results (250-300 rpm), the highest conversion value was obtained with the ChCl:Gly $(1: 2$ $\mathrm{mol} / \mathrm{mol}$ ) at $300 \mathrm{rpm}$ for a $87 \%$ conversion and a very high selectivity towards the formation of the aldol product $3 \mathbf{a}(8: 1)$.

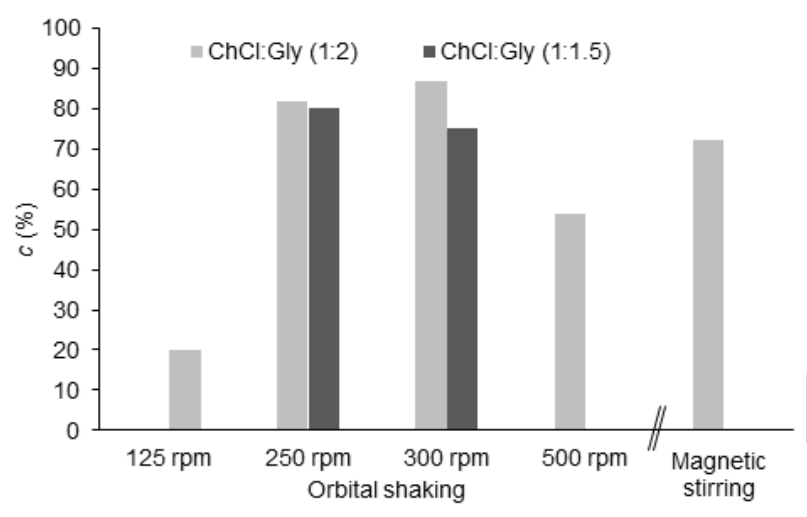

Figure 3. PPL-catalysed aldol reaction between 1a (1:2 enzyme:aldehyde $\mathrm{w} / \mathrm{w})$ and 5 equiv. of acetone in $\mathrm{ChCl}$ :Gly mixtures containing a $5 \%$ of water after $24 \mathrm{~h}$ using different types of agitation.

\section{Hydrolase-catalysed aldol reaction between substituted benzaldehydes and acetone}

With the best results in hand (entry 9, Table 2), we decided to explore the suitability of these DES systems with a family of acceptors (benzaldehydes with different pattern substitutions in the aromatic ring 1a-e) and donors (acetone, cyclopentanone and cyclohexanone) for the PPL-catalysed aldol reaction (Tables 3, 4 and 5). Firstly, benzaldehydes 1ae were tested in the reaction with 5 equivalents of acetone and the results are summarised in Table 3.

Satisfyingly, in all cases the final products were obtained with almost quantitative conversions in all cases (entries 1-5). The aldol adducts 3a-e were identified for all the tested substrates as the major products, although a significant amount of the aldol-dehydration compounds $4 \mathbf{a}-\mathbf{e}$ was attained, especially for the 3-nitrobenzaldehyde (entry 2) or when weaker electron withdrawing groups are present in the aromatic ring (entries 4 and 5). Unfortunately, the approach seems to be not highly efficient when 2-cyanobenzaldehyde or the own benzaldehyde were used as, respectively, undesired polymerization side reactions and complex product mixtures were observed.
Table 3. PPL-catalysed aldol reaction between substituted benzaldehydes 1a-e and 5 equiv. of acetone using PPL (1:1 enzyme:aldehyde w/w) in ChCl:Gly (1:2 mol/mol) and $5 \%$ of water after $24 \mathrm{~h}$ at $60^{\circ} \mathrm{C}$ and $250 \mathrm{rpm}$.

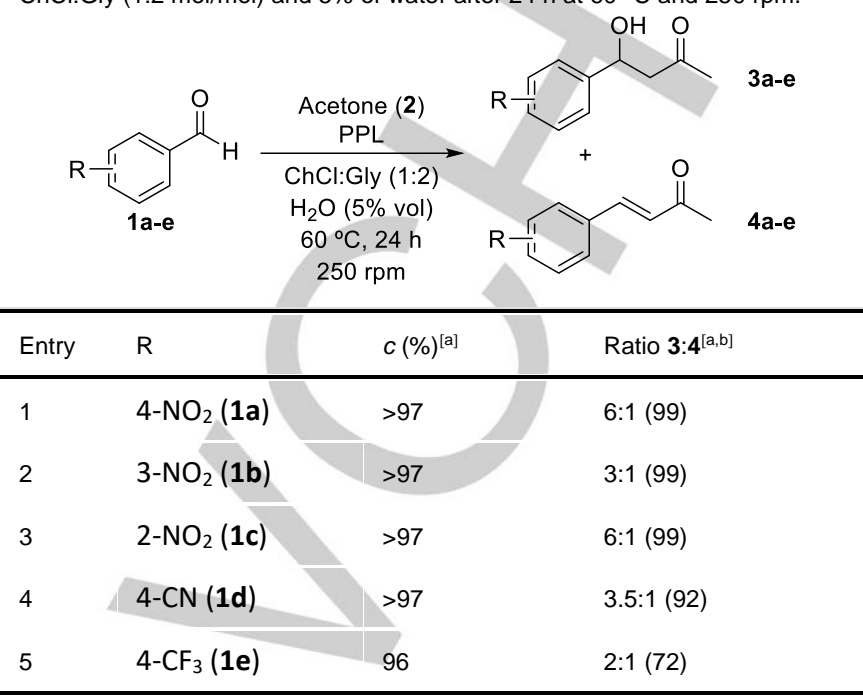

[a] Conversion values and ratio of products 3:4 were determined by ${ }^{1} \mathrm{H}-\mathrm{NMR}$ of the reaction crudes. [b] Isolated yields after five liquid-liquid extractions with EtOAc are shown in brackets.

Hydrolase-catalysed aldol reaction between substituted benzaldehydes and cyclic aliphatic ketones

Other ketones, in this case cyclic ones such as cyclopentanone (5) and cyclohexanone (6), were used (Tables 4 and 5). The reaction between 4-nitrobenzaldehyde and cyclohexanone was firstly analysed in depth, studying the effect of using variable enzyme loadings, equivalents of cyclohexanone and percentages of water (Table 4).

As expected, the reaction in the absence of PPL did not procced in any extension, obtaining a noteworthy $82 \%$ conversion when using PPL in a 1:2 ratio in weight with respect to the substrate (entry 2). Slightly higher conversions could be achieved in the presence of water although the use of up to $20 \%$ of water did not provide significant changes (86-87\% conversion, entries 3-6). Gratifyingly, other benzaldehydes reacted to reach the corresponding aldol products in good to high yield (entries 7-9). Finally, the use of a higher loading of enzyme in the reaction with 4nitrobenzaldehyde (1a) with a higher excess of cyclohexanone (2 equiv.) led to the final product in quantitative conversion (entry 10 ). It must be mentioned that the corresponding aldol-dehydration product was not observed in any case. In addition, just two equivalents were required to achieve full conversion in comparison to a large excess for the aldol reactions with acetone (5 equiv.). 
Table 4. PPL-catalysed aldol reaction between substituted nitrobenzaldehydes (1a-c, $1 \mathrm{M}$ ) and cyclohexanone (6) in ChCl:Gly (1:2 $\mathrm{mol} / \mathrm{mol}$ ) after $24 \mathrm{~h}$ at $60^{\circ} \mathrm{C}$ and $250 \mathrm{rpm}$.

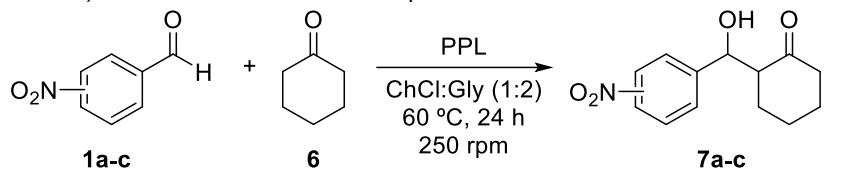

\begin{tabular}{lllll}
\hline Entry & PPL:1 ${ }^{[a]}$ & {$[\mathbf{6}](\mathrm{M})$} & $\mathrm{H}_{2} \mathrm{O}(\%)^{[\mathrm{b}]}$ & $c(\%)^{[\mathrm{c}, \mathrm{d}]}$ \\
\hline 1 & $0: 1(\mathbf{1 a})$ & 1.1 & 0 & $<3$ \\
2 & $1: 2(\mathbf{1 a})$ & 1.1 & 0 & $82(56: 44)$ \\
3 & $1: 2(\mathbf{1 a})$ & 1.1 & 5 & $86(54: 46)$ \\
4 & $1: 2(\mathbf{1 a})$ & 1.1 & 10 & $87(54: 46)$ \\
5 & $1: 2(\mathbf{1 a})$ & 1.1 & 15 & $87(53: 47)$ \\
6 & $1: 2(\mathbf{1 a})$ & 1.1 & 20 & $87(53: 47)$ \\
\hline 7 & $1: 1(\mathbf{1 a})$ & 1.1 & 5 & $92(57: 43)$ \\
8 & $1: 1(\mathbf{1 b})$ & 1.1 & 5 & $88(53: 47)$ \\
9 & $1: 1(\mathbf{1 c})$ & 1.1 & 5 & $70(52: 48)$ \\
10 & $1: 1(\mathbf{1 a})$ & 2.0 & 5 & $>97(55: 45)$ \\
\hline
\end{tabular}

[a] Ratio enzyme:aldehyde 1a-c (w/w). [b] Percentage in volume of water in the reaction medium. [c] Conversion values were determined by ${ }^{1} \mathrm{H}-\mathrm{NMR}$ analysis of the reaction crudes. [d] Diastereomeric ratio were also calculated by ${ }^{1} \mathrm{H}-\mathrm{NMR}$ analysis and the ratios syn:anti appears in parentheses.

This synthetic approach was extended to a series of aldehydes 1a-e using both cyclopentanone and cyclohexanone, obtaining the aldol products as major products and in quantitative conversions for most of the substrates (Table 5). A total conversion was observed for all the benzaldehydes used without substitutions in the orthoposition, isolating the aldol products $7 \mathbf{a}-\mathbf{e}$ and $8 \mathbf{a}-\mathbf{e}$ as major products although with poor diastereoselectivities. The reactions with cyclohexanone highly favoured the formation of the aldols 7a-e as the corresponding products resulting from the dehydration process was just observed in percentages up to $7 \%$ (even entries). For the reactions with the cyclopentanone (odd entries) the 4-nitrobenzaldehyde seems to be the perfect donor as the aldol product was obtained in excellent yield (entry 1 ).

\section{Recycling studies of the DES and the enzyme}

To fully disclose the potential of DES, the recycling of DES and the enzyme was studied for a selected reaction, so using 4-nitrobenzaldehyde and 2 equiv. of cyclohexanone (entry 2, Table 5). The enzyme and the DES were recovered after the biotransformations, prior extraction of the target products with ethyl acetate. Then the catalytic system was immediately used, measuring the activity after $24 \mathrm{~h}$ (Figure 4).

The recycling experiments were conducted up to four times, a significant loss of activity being observed after the first cycle, which made us think in a deactivation of the biocatalyst in the early stage of the process due to the severe reaction conditions (high substrates concentration and $60^{\circ} \mathrm{C}$ ). This was not surprising as the enzyme was used as an enzymatic crude without being immobilized in any support, which highlights the possibility of recycling the biocatalyst together with the DES medium. Next, the activity of the catalytic system decreased continuously after every reuse, although the drop of activity was more alleviated for the consecutive runs. The diastereomeric ratio of the product $7 \mathrm{a}$ was not affected along the repetitive experiments and the alcohol-dehydration product 9a was never observed.

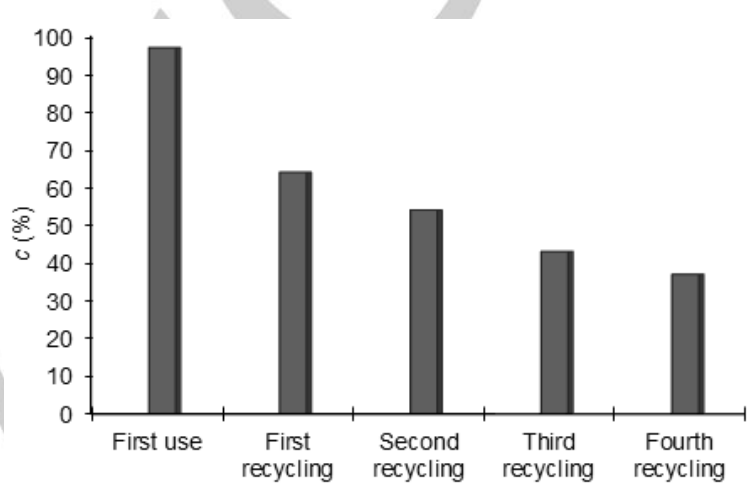

Figure 4. Recycling experiments in the reaction between 4-nitrobenzaldehyde (1a, $1 \mathrm{M})$ and cyclohexanone $(\mathbf{6}, 2.0$ equiv.) using $\mathrm{PPL}(1: 1 \mathrm{w} / \mathrm{w}$ ratio with $1 \mathrm{a})$ in $\mathrm{ChCl}$ :Gly (1:2) and $5 \%$ of water after $24 \mathrm{~h}$ at $60^{\circ} \mathrm{C}$ and $250 \mathrm{rpm}$.

\section{Conclusions}

Deep eutectic solvents represent nowadays a promising alternative to conventional organic volatile solvents. For the first time, a promiscuous lipase-catalysed aldol reaction has been performed in this type of neoteric solvents. Porcine pancreas lipase (PPL) has generally led to the aldol product in excellent conversions after an exhaustive optimization of the reaction conditions, the corresponding $\alpha, \beta$-unsaturated carbonyl compounds being found in low percentages, which was formed as a result of the dehydration of the so-obtained alcohol product. This research opens new possibilities in synthetic chemistry, so the study of new hydrolase-catalysed non conventional reactions in deep eutectic solvents is underway.

\section{Experimental Section}

Porcine pancreas lipase (PPL) type II (30-90 U/mg of protein using triacetin) and protease from Bacillus licheniformis (Alcalase-CLEA ${ }^{\circledR}, 5.81 \mathrm{U} / \mathrm{g}$ ) were purchased from SigmaAldrich. Candida antarctica lipase type B (CAL-B, Novozyme 435, 7300 PLU/g) was a gift from Novozymes (Denmark). All other reagents and solvents were used as received from commercial suppliers without further purification. 
Table 5. Enzyme-catalysed aldol reaction between benzaldehydes (1a-e, $1 \mathrm{M})$ and cycloalkanones (5 and 6, 2.0 equiv.) using a PPL:aldehyde (1:1 ratio w/w) in $\mathrm{ChCl}: G l y ~(1: 2)$ and $5 \%$ of water after $24 \mathrm{~h}$ at $60^{\circ} \mathrm{C}$ and $250 \mathrm{rpm}$.
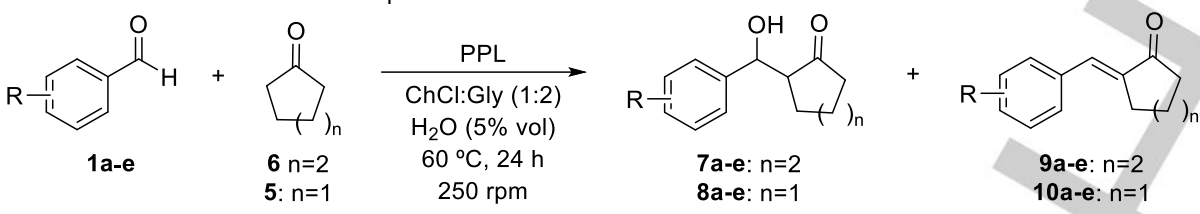

\begin{tabular}{|c|c|c|c|c|c|}
\hline Entry & Aldehyde & Ketone & $c(\%)^{[\mathrm{a}]}$ & Aldol 7,8 $d r(\%)^{[\mathrm{a}]}$ & Aldol-dehydration product $\mathbf{9 , 1 0}$ \\
\hline 1 & $1 \mathrm{a}\left(\mathrm{R}=4-\mathrm{NO}_{2}\right)$ & 5 & $>97(93)$ & $55: 45$ & 3 \\
\hline 2 & 1a $\left(\mathrm{R}=4-\mathrm{NO}_{2}\right)$ & 6 & $>97(89)$ & $55: 45$ & $<3$ \\
\hline 3 & 1b $\left(\mathrm{R}=3-\mathrm{NO}_{2}\right)$ & 5 & $>97$ (99) & $57: 43$ & 13 \\
\hline 5 & $1 \mathrm{c}\left(\mathrm{R}=2-\mathrm{NO}_{2}\right)$ & 5 & 55 (n.d.) & $53: 47$ & $<3$ \\
\hline 6 & $1 c\left(R=2-\mathrm{NO}_{2}\right)$ & 6 & 70 (n.d.) & $55: 45$ & $<3$ \\
\hline 7 & $1 \mathrm{~d}(\mathrm{R}=4-\mathrm{CN})$ & 5 & $>97$ (99) & $61: 39$ & 11 \\
\hline 8 & $1 d(R=4-C N)$ & 6 & $>97(96)$ & $52: 48$ & $<3$ \\
\hline 10 & $1 e\left(R=4-C F_{3}\right)$ & 6 & >97 (99) & $55: 45$ & $<3$ \\
\hline
\end{tabular}

[a] Conversion, diastereomeric ratio of the aldol product and percentage of the alcohol-dehydration product values were determined by ${ }^{1} \mathrm{H}-\mathrm{NMR}$ of the reaction crudes. n.d.: not determined. [b] An additional $8 \%$ of a polycondensation product was also observed.

Column chromatographies were performed using silica gel 60 (230-240 mesh) purchased from Merck. ${ }^{1} \mathrm{H},{ }^{13} \mathrm{C}$ and DEPT NMR experiments were performed using AC-300 and DPX-300 Brüker spectrometers at room temperature $\left({ }^{1} \mathrm{H}\right.$, $300.13 \mathrm{MHz}$ and $\left.{ }^{13} \mathrm{C}, 75.5 \mathrm{MHz}\right)$. Conversion and diastereomeric ratio values were calculated by ${ }^{1} \mathrm{H}-\mathrm{NMR}$ analysis by comparing the $\mathrm{CH}$ signal adjacent to the hydroxyl group (see Supporting Information for further details). ${ }^{24}$

\section{General procedure for the ChCl:Gly (1:2) DES preparation}

Choline chloride $(50.0 \mathrm{mmol}, 6.98 \mathrm{~g})$ and glycerol (100.0 $\mathrm{mmol}, 7.30 \mathrm{~mL}$ ) were mixed together and stirred at $80{ }^{\circ} \mathrm{C}$ until a clear solution was obtained (30 min). After cooling down to room temperature, the formed DES could be used directly in lipase-catalysed reaction without further purification. For the preparation of $\mathrm{ChCl}$ :Gly $(1: 1.5)$ the protocol was the same but using $75.0 \mathrm{mmol}$ of glycerol (5.48 $\mathrm{mL})$. General procedure for the aldol reaction between 4-
nitrobenzaldehyde and acetone in DES

A mixture of porcine pancreas lipase (PPL, $151 \mathrm{mg}$ ), 4nitrobenzaldehyde (1a, $151 \mathrm{mg}, 1.0 \mathrm{mmol})$ and acetone $(\mathbf{2}$, $368 \mu \mathrm{L}, 5.0 \mathrm{mmol})$ in choline chloride:glycerol $(1: 2 \mathrm{~mol} / \mathrm{mol}, 1$ $\mathrm{mL})$ containing a $5 \%$ of water $(50 \mu \mathrm{L})$ was shaken at $60{ }^{\circ} \mathrm{C}$ and $250 \mathrm{rpm}$. After $24 \mathrm{~h}$ the mixture was extracted with ethyl acetate $(5 \times 5 \mathrm{~mL})$. The combined organic layers were washed with brine $(2 \times 10 \mathrm{~mL})$, dried over $\mathrm{Na}_{2} \mathrm{SO}_{4}$ and filtered, evaporating the solvent under reduced pressure. The mixture of aldol products were isolated as an orange solid, and their composition analysed by ${ }^{1} \mathrm{H}-\mathrm{NMR}$ analysis.

General procedure for the aldol reaction between benzaldehydes and acetone in DES

A mixture of porcine pancreas lipase (PPL, $151 \mathrm{mg}$ ), the corresponding aldehyde (1a-e, $1.0 \mathrm{mmol})$ and acetone (2 $368 \mu \mathrm{L}, 5.0 \mathrm{mmol})$ in choline chloride:glycerol $(1: 2 \mathrm{~mol} / \mathrm{mol}, 1$ $\mathrm{mL})$ containing a $5 \%$ of water $(50 \mu \mathrm{L})$ was shaken at $60{ }^{\circ} \mathrm{C}$ and $250 \mathrm{rpm}$. After $24 \mathrm{~h}$ the mixture was extracted with ethyl acetate $(5 \times 5 \mathrm{~mL})$. The combined organic layers were washed with brine $(2 \times 10 \mathrm{~mL})$, dried over $\mathrm{Na}_{2} \mathrm{SO}_{4}$ and filtered, evaporating the solvent under reduced pressure. The mixture of aldol products were isolated, and their composition analysed by ${ }^{1} \mathrm{H}-\mathrm{NMR}$ analysis.

General procedure for the aldol reaction between benzaldehydes and cyclic aliphatic ketones in DES

A mixture of porcine pancreas lipase (PPL, $151 \mathrm{mg}$ ), 4nitrobenzaldehyde (1a-e, $1.0 \mathrm{mmol})$ and cyclopentanone (5, $107 \mu \mathrm{L}, 2.0 \mathrm{mmol}$ ) or cyclohexanone $(6,207 \mu \mathrm{L}, 2.0 \mathrm{mmol})$ in choline chloride:glycerol $(1: 2 \mathrm{~mol} / \mathrm{mol}, 1 \mathrm{~mL})$ containing a $5 \%$ of water $(50 \mu \mathrm{L})$ was shaken at $60^{\circ} \mathrm{C}$ and $250 \mathrm{rpm}$. After 24 $\mathrm{h}$ the mixture was extracted with ethyl acetate $(5 \times 5 \mathrm{~mL})$. The combined organic layers were washed with brine $(2 \times 10$ $\mathrm{mL}$ ), dried over $\mathrm{Na}_{2} \mathrm{SO}_{4}$ and filtered, evaporating the solvent under reduced pressure. The mixture of aldol products were isolated, and their composition analysed by ${ }^{1} \mathrm{H}-\mathrm{NMR}$ analysis. 


\section{Acknowledgements}

Financial support to this work was provided by Ministerio de Economía y Competitividad (CTQ2013-44153-P) and Gobierno del Principado de Asturias (FC-15-GRUPIN14-002). The authors thank Novo Nordisk Co. for the generous gift of CAL-B (Novozyme 435). D.G.-M. thanks FICYT for a predoctoral fellowship.

Keywords: Aldol reaction - Biocatalytic promiscuity • Biotransformations $\cdot$ Deep eutectic solvents $\cdot$ Hydrolases

[1] a) P. J. O'Brien, D. Herschlag, Chem. Biol. 1999, 6, R91-R105; b) U. T. Bornscheuer, R. J. Kazlauskas, Angew. Chem. Int. Ed. 2004, 43, 6032 6040 ; c) K. Hult, P. Berglund, Trends Biotechnol. 2007, 25, 231-238; d) I. Nobeli, A. D. Favia, J. M. Thornton, Nat. Biotechnol. 2009, 27, 157167.

[2] a) E. Busto, V. Gotor-Fernández, V. Gotor, Chem. Soc. Rev. 2010, 39, 4504-4523; b) M. Kapoor, M. N. Gupta, Process Biochem. 2012, 47 555-569; c) M. López-Iglesias, V. Gotor-Fernández, Chem. Rec. 2015, 15, 743-759.

[3] a) U. T. Bornscheuer, R. J. Kazlauskas, Hydrolases in Organic Synthesis: Regio- and Stereoselective Biotransformations, $2^{\text {nd }}$ Ed. Wiley-VCH: Weinheim (Germany), 2005; b) V. Gotor-Fernández, V. Gotor, Curr. Org. Chem. 2006, 10, 1125-1143; c) V. Gotor-Fernández, R. Brieva, V. Gotor, J. Mol. Catal. B: Enzym. 2006, 40, 111-120; d) A. Ghanem, Tetrahedron 2007, 63, 1721-1754.

[4] a) Q. Wu, B.-K. Liu, X.-F. Lin, Curr. Org. Chem. 2010, 14, 1966-1988; b) M. S. Humble, P. Berglund, Eur. J. Org. Chem. 2011, 3391-3401; c) Z. Guan, L.-Y. Li, Y.-H. He, RSC Adv. 2015, 5, 16801-16814.

[5] a) M. Hayyan, M. A. Hashim, A. Hayyan, M. A. Al-Saadi, I. M. AINashef, M. E. S. Mirghani, O. K. Saheed, Chemosphere 2013, 90, 2193-2195; b) M. Hayyan, M. A. Hashim, M. A. Al-Saadi, A. Hayyan, I. M. AlNashef, M. E. S. Mirghani, Chemosphere 2013, 93, 455-459; c) I. Juneidi, M. Hayyan, M. A. Hashim, RSC Adv. 2015, 5, 83636-83647.

[6] a) Q. Zhang, K. D. O. Vigier, S. Royer and F. Jérôme, Chem. Soc. Rev. 2012, 41, 7108-7146; b) E. L. Smith, A. P. Abbott, K. S. Ryder, Chem. Rev. 2014, 114, 11060-11082; c) J. I. García, H. García-Marín, E. Pires Green Chem. 2014, 16, 1007-1033.

[7] A. P. Abbott, E. I. Ahmed, R. C. Harris, K. S. Ryder, Green Chem. 2014, $16,4156-4161$.

[8] D. V. Wagle, H. Zhao, G. A. Baker, Acc. Chem. Res. 2014, 47, 22992308.

[9] S. Cherukuvada, A. Nangia, Chem. Commun. 2014, 50, 906-923.

[10] F. Pena-Pereira, J. Namieśnik, ChemSusChem 2014, 7, 1784-1800.

[11] P. Liu, J.-W. Hao, L.-P. Mo, Z.-H. Zhang, RSC Adv. 2015, 5, 4867548704.

[12] a) J. García-Álvarez, Eur. J. Inorg. Chem. 2015, 5147-5157; b) J. García-Álvarez, E. Hevia, V. Capriati, Eur. J. Org. Chem. 2015, 67796799.
[13] M. K. Potdar, G. F. Kelso, L. Schwarz, C. Zhang, M. T. W. Hearn, Molecules 2015, 20, 16788.

[14] a) J. T. Gorke, F. Srienc, R. J. Kazlauskas, Chem. Commun. 2008 1235-1237; b) D. Lindberg, M. F. Revenga, M. Widersten, J. Biotechnol. 2010, 147, 169-171; c) H. Zhao, G. A. Baker, S. Holmes, Org. Biomol. Chem. 2011, 9, 1908-1916; d) H. Zhao, G. A. Baker, S. Holmes, J. Mol. Catal. B: Enzym. 2011, 72, 163-167; e) E. Durand, J. Lecomte, B. Baréa, G. Piombo, E. Dubreucq, P. Villeneuve, Process Biochem. 2012, 47, 2081-2089; f) H. Zhao, C. Zhang, T. D. Crittle, J. Mol. Catal. B: Enzym. 2013, 85-86, 243-247; g) Z. Maugeri, W. Leitner, P. Domínguez de María, Eur. J. Org. Chem. 2013, 4223-4228; h) E. Durand, J. Lecomte, B. Baréa, E. Dubreucq, R. Lortie, P. Villeneuve, Green Chem. 2013, 15, 2275-2282; i) E. Fernández-Álvaro, J. Esquivias, M. PérezSánchez, P. Domínguez de María, M. J. Remuiñán-Blanco, J. Mol. Catal. B: Enzym. 2014, 100, 1-6; j) A. Petrenz, P. Domínguez de María, A. Ramanathan, U. Hanefeld, M. B. Ansorge-Schumacher, S. Kara, J. Mol. Catal. B: Enzym. 2015, 114, 42-49; k) M. C. Bubalo, A. J. Tušek, M. Vinković, K. Radošević, V. G. Srček, I. R. Redovniković, J. Mol. Catal. B: Enzym. 2015, 122, 188-198.

[15] a) K. Fujita, N. Nakamura, K. Igarashi, M. Samejima, H. Ohno, Green Chem. 2009, 11, 351-354; b) Z. Maugeri, P. Domínguez de María, ChemCatChem 2014, 6, 1535-1537; c) P. Xu, J. Cheng, W.-Y. Lou, M. H. Zong, RSC Adv. 2015, 5, 6357-6364; d) C. R. Müller, I. Lavandera, V. Gotor-Fernández, P. Domínguez de María, ChemCatChem 2015, 7, 2654-2659.

[16] a) Z. Maugeri, P. Domínguez de María, J. Mol. Catal. B: Enzym. 2014 107, 120-123; b) B.-P. Wu, Q. Wen, H. Xu, Z. Yang, J. Mol. Catal. B: Enzym. 2014, 101, 101-107.

[17] a) C. R. Müller, I. Meiners, P. Domínguez de María, RSC Adv. 2014, 4, 46097-46101; b) C. R. Müller, A. Rosen, P. Domínguez de María Sustain. Chem. Process. 2015, 3, 12

[18] B. N. Borse, V. S. Borude, S. R. Shukla, Curr. Chem. Lett. 2012, 1, 59 68.

[19] a) C. Branneby, P. Carlqvist, A. Magnusson, K. Hult, T. Brinck, P. Berglund, J. Am. Chem. Soc. 2003, 125, 874-875; b) C. Branneby, P. Carlqvist, K. Hult, T. Brinck, P. Berglund, J. Mol. Catal. B: Enzym. 2004, 31, 123-128; c) A. B. Majumder, N. G. Ramesh, M.-N. Gupta Tetrahedron Lett. 2009, 50, 5190-5193.

[20] M. López-Iglesias, E. Busto, V. Gotor-Fernández, V. Gotor, Adv. Synth. Catal. 2011, 353, 2345-2353.

[21] a) C. Li, X.-W. Feng, N. Wang, Y.-J. Zhou, X.-Q. Yu, Green Chem. 2008, 10, 616-618; b) Z. Guan, J.-P. Fu, Y.-H. He, Tetrahedron Lett. 2012, 53, 4959-4961; c) Z.-B. Xie, N. Wang, L.-H. Zhou, F. Wang, T. He, Z.-G. Le, X.-Q. Yu, ChemCatChem 2013, 5, 1935-1940; d) J. Zheng, B.-H. Xie, Y.-L. Chen, J.-F. Cao, Y. Yang, Z. Guan, Y.-H. He, Z. Naturforsch. 2014, 69c, 170-180.

[22] E. Busto, V. Gotor-Fernández, V. Gotor, Org. Process Res. Dev. 2011, 15, 236-240.

[23] Y. Cai, X.-F. Sun, N. Wang, X.-F. Lin, Synthesis 2004, 671-674.

[24] Y. Qian, X. Zheng, Y. Wang, Eur. J. Org. Chem. 2010, 3672-3677. 


\section{Entry for the Table of Contents}

\section{FULL PAPER}

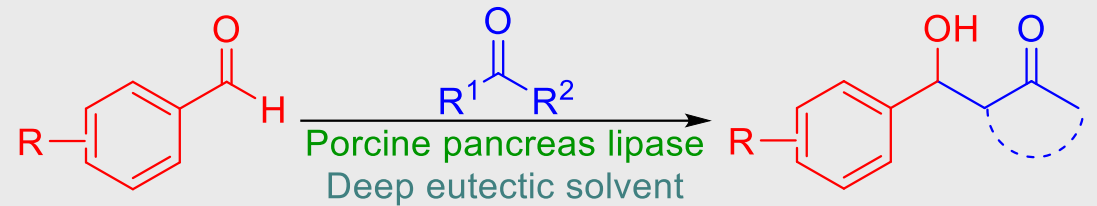

Deep eutectic solvents have been used for the first time in promiscuous lipasecatalysed aldol reactions. The reaction between substituted benzaldehydes and aliphatic ketones was examined in depth, an excellent compatibility being found between porcine pancreas lipase (PPL) and choline chloride: glycerol mixtures for the formation of the aldol product in high yields. Control experiments demonstrate that PPL was also responsible of a collateral dehydration reaction.

\section{Biocatalytic promiscuity}

Daniel González-Martínez, Vicente Gotor and Vicente Gotor-Fernández

\section{Page No. - Page No.}

Application of deep eutectic solvents in promiscuous lipase-catalysed aldol reactions 